\title{
Differential effects of leptin and refeeding on the fasting-induced decrease of pituitary type 2 deiodinase and thyroid hormone receptor $\beta 2$ mRNA expression in mice
}

\author{
A Boelen, J Kwakkel, X G Vos, W M Wiersinga and E Fliers \\ Department of Endocrinology, Metabolism, F5-165, Academic Medical Center, University of Amsterdam, Meibergdreef 9, 1105 AZ Amsterdam, \\ The Netherlands \\ (Requests for offprints should be addressed to A Boelen; Email: a.boelen@amc.uva.nl)
}

\begin{abstract}
Profound changes in thyroid hormone metabolism occur in the central part of the hypothalamus-pituitary-thyroid (HPT) axis during fasting. Hypothalamic changes are partly reversed by leptin administration, which decreases during fasting. It is unknown to what extent leptin affects the HPT axis at the level of the pituitary. We, therefore, studied fasting-induced alterations in pituitary thyroid hormone metabolism, as well as effects of leptin administration on these changes. Because refeeding rapidly increased serum leptin, the same parameters were studied after fasting followed by refeeding. Fasting for $24 \mathrm{~h}$ decreased serum $\mathrm{T}_{3}$ and $\mathrm{T}_{4}$ and pituitary TSH $\beta$, type 2 deiodinase (D2), and thyroid hormone receptor $\beta 2$ (TR $\beta 2)$ mRNA expression. The decrease in D2 and TR $\beta 2$ mRNA expression was prevented when $20 \mu \mathrm{g}$ leptin was administered twice during fasting. By contrast, the decrease in TSH $\beta$
\end{abstract}

mRNA expression was unaffected. A single dose of leptin given after $24 \mathrm{~h}$ fasting did not affect decreased TSH $\beta$, D2, and TR $\beta 2$ mRNA expression, while $4 \mathrm{~h}$ refeeding resulted in pituitary D2 and TR $\beta 2$ mRNA expression as observed in control mice. Serum leptin, $\mathrm{T}_{3}$, and $\mathrm{T}_{4}$ after refeeding were similar compared with leptin administration. We conclude that fasting decreases pituitary TSH $\beta, \mathrm{D} 2$, and TR $\beta 2 \mathrm{mRNA}$ expression, which (with the exception of TSH $\beta$ ) can be prevented by leptin administration during fasting. Following $24 \mathrm{~h}$ fasting, $4 \mathrm{~h}$ refeeding completely restores pituitary D2 and TR $\beta 2$ mRNA expression, while a single leptin dose is ineffective. This indicates that other postingestion signals may be necessary to modulate rapidly the fasting-induced decrease in pituitary D2 and TR $\beta 2$ mRNA expression.

Journal of Endocrinology (2006) 190, 537-544

\section{Introduction}

During fasting, profound changes occur in the hypothalamic part of the hypothalamic-pituitary-thyroid axis (HPT axis), i.e. increased type 2 deiodinase (D2) activity in the arcuate nucleus (ARC) (Diano et al. 1998) and decreased thyrotropinreleasing hormone $(\mathrm{TRH})$ expression in the paraventricular nucleus (PVN) (Blake et al. 1991). Locally produced $\mathrm{T}_{3}$ by $\mathrm{D} 2$ has been proposed to contribute to the decrease in TRH expression in the PVN, which induces persistently decreased serum thyroid hormones via decreased pituitary thyroidstimulating hormone (TSH) subunit mRNA expression (Wiersinga 2005).

The observed modest increase in hypothalamic D2 activity during fasting (Diano et al. 1998) is in contrast with the rapid, twofold increase in D2 activity (Fekete et al. 2004) and mRNA expression in the hypothalamus (Boelen et al. 2004) during acute inflammation as observed in an animal model of illness. It has been hypothesized that cytokines might be involved in the inflammation-related changes in hypothalamic D2 expression, while other factors might be involved in fasting-related changes. It is known that corticosteroids (van Haasteren et al. 1995) and leptin are involved in the fasting-induced decrease of TRH expression in the PVN. TRH mRNA expression is downregulated in the PVN during fasting and partly restored by leptin administration (Legradi et al. 1997). Furthermore, leptin administration during fasting reverses the increase in serum corticosterone in rats (Ahima et al. 1996) and a recent study by Coppola et al. (2005) has shown that only a combination of lowered serum leptin levels and increased serum glucocorticoid concentrations resulted in elevated hypothalamic D2 activity during fasting.

Leptin, an adipocyte-derived hormone, regulates food intake, energy expenditure, and endocrine function by signaling via specific hypothalamic pathways. It affects TRH synthesis both directly and indirectly via the TRH gene promoter (Guo et al. 2004) and via pro-opiomelanocortin (POMC) and agouti-related protein (AGRP) expression in the ARC (Flier et al. 2000) respectively. It is, however, unknown how leptin influences pituitary thyroid hormone metabolism during fasting. The anterior pituitary expresses 
both leptin and leptin receptors in TSH-producing cells (Jin et al. 2000). Furthermore, incubation of rat pituitary cells with leptin results in an increase of TSH $\beta$ mRNA expression (Chowdhury et al. 2004), although others have shown that isolated hemi-pituitaries of the rat respond to leptin by decreasing TSH release (Ortiga-Carvalho et al. 2002).

In summary, food deprivation induces downregulation of the HPT axis at various levels, while serum leptin decreases as well. Refeeding restores fasting-induced HPT axis changes, while exogenous leptin administration restores these changes only to some extent. We, therefore, hypothesized differential effects of refeeding and leptin administration to fasted mice on deiodinase, TSH, and thyroid hormone receptor (TR) gene expression in the anterior pituitary. The aim of the present study was, therefore, to evaluate fasting-induced alterations in pituitary TSH $\beta, \mathrm{D} 2$, and TR $\beta 2$ mRNA expression, as well as the effect of leptin administration on these changes. Because refeeding results in a rapid increase in leptin levels, the expression of TSH $\beta, D 2$, and TR $\beta 2$ mRNA was also studied upon refeeding after fasting.

\section{Materials and Methods}

\section{Animals}

Female Balb/c mice (Harlan Sprague Dawley, Horst, The Netherlands) weighing approximately $20 \mathrm{~g}$ were used at $6-12$ weeks of age. The mice were kept in $12 \mathrm{~h}$ light: $12 \mathrm{~h}$ darkness cycles (lights on from 0700 to $1900 \mathrm{~h}$ ), in a temperaturecontrolled room $\left(22^{\circ} \mathrm{C}\right)$ and food and water were available ad libitum. A week before and during the experiment, the mice were housed in groups according to the experimental setup. We performed three types of experiments and the study was approved by the Local Animal Welfare Committee of the Academic Medical Center, University of Amsterdam.

\section{Experimental protocols}

Experiment 1 Two groups of mice $(n=6 /$ group $)$ were fasted for $24 \mathrm{~h}$, one group received $20 \mu \mathrm{g}$ leptin $/ 0.5 \mathrm{ml}$ $0.01 \mathrm{M} \mathrm{NaHCO}_{3}$ intraperitoneally (recombinant mouse leptin, obtained from Dr Parlow, Harbor-UCLA Medical Center, Torrance, CA, USA). Leptin was administered twice (at $0900 \mathrm{~h}(t=0 \mathrm{~h})$ and $1700 \mathrm{~h}(t=8 \mathrm{~h}))$ in this period. The other group received vehicle. Both groups were compared with control mice $(n=6)$, that received vehicle and had free access to food.

Experiment 2 Two groups of mice ( $n=6 /$ group) were fasted for $24 \mathrm{~h}$ and, subsequently, leptin was given at $0900 \mathrm{~h}$ $\left(t=24\right.$ h, i.p. $\left.20 \mu \mathrm{g} / 0.5 \mathrm{ml} \mathrm{0.01} \mathrm{M} \mathrm{NaHCO}_{3}\right)$. One group was killed at $28 \mathrm{~h}$ and the other at $32 \mathrm{~h}$. Both groups were compared with fed control mice that also received leptin at $24 \mathrm{~h}$ and were killed at 28 and $32 \mathrm{~h}$.
Experiment 3 Two groups of mice ( $n=6 /$ group) were fasted for $24 \mathrm{~h}$ and refed for either 4 or $24 \mathrm{~h}$. Food was reintroduced at $0900 \mathrm{~h}$. The groups were compared with fed control mice, which were also euthanized at the same time points.

Because of the diurnal variation of thyroid hormonerelated genes, the experiments were performed using the same time schedule starting at $0900 \mathrm{~h}(t=0)$. Furthermore, each time point has its own control group. In all experiments, mice were anesthetized with isoflurane, blood was taken by cardiac puncture and then mice were killed by cervical dislocation. Serum was stored at $-20{ }^{\circ} \mathrm{C}$ until analyzed. The pituitary and hypothalamus (defined rostrally by the optic chiasma, caudally by the mamillary bodies, laterally by the optic tract, and dorsally by the apex of the third ventricle) were isolated and stored immediately in liquid nitrogen. Based on anatomical landmarks (the apex of the third ventricle (Franklin 1997)), the PVN was obtained by punching the hypothalamus with a hollow needle (diameter $1100 \mu \mathrm{m})$.

\section{Serum determinations}

Serum $T_{3}$ and $T_{4}$ were measured with in-house RIAs (Wiersinga \& Chopra 1982). Serum leptin levels were measured with ELISA (Crystal Chem, Inc., Downers Grove, IL, USA). To prevent interassay variation, all samples of one experiment were measured within the same assay.

\section{RNA isolation and RT-PCR}

mRNA was isolated from the PVN and pituitary using the Magna Pure apparatus and the Magna Pure LC mRNA isolation kit II (tissue; Roche Biochemicals) according to the manufacturer's protocol and cDNA synthesis was performed with the first strand cDNA synthesis kit for reverse transcriptase (RT)-PCR (AMV; Roche Molecular Biochemicals). Published primer pairs were used to amplify hypoxanthine phosphoribosyl transferase (HPRT), a housekeeping gene (Sweet et al. 2001). We designed primer pairs for D2, TR $\beta 2$, TSH $\beta$, and preproTRH (Boelen et al. 2004). Real-time PCR was performed for quantitation of the abovementioned mRNAs. cDNA standards for the different mRNAs were prepared from RNA of murine liver, pituitary, or hypothalamus. For each mRNA assayed, a standard curve was generated using tenfold serial dilutions of this target standard PCR product and the same primers used to amplify the cDNA. For each gene, the standard protocol was optimized by varying $\mathrm{MgCl}_{2}$ concentrations. PCR were setup with cDNA, $\mathrm{MgCl}_{2}(25 \mathrm{mM}$ ), SybrGreenI (Roche Molecular Biochemicals), forward and reverse primer and $\mathrm{H}_{2} \mathrm{O}$. The reactions were then cycled in the LightCycler (Roche Molecular Biochemicals) as described before (Boelen et al. 2004). The LightCycler software generated a standard curve (measurements taken during the exponential phase of 
the amplification), which enabled the amount of each mRNA in each test sample to be determined. All results were corrected as to their mRNA content using HPRT mRNA. Samples were individually checked for their PCR efficiency (Ramakers et al. 2003). The median of the efficiency was calculated for each assay and samples with a greater than $0 \cdot 05$ difference of the efficiency median value were not taken into account.

\section{Statistical analysis}

Data were normally distributed (Shapiro-Wilk test) and are presented as the mean \pm s.E.M. Variation between fasted mice, treated with leptin or refed and control fed mice, was evaluated by ANOVA with two grouping factors (time and treatment) and their interaction followed by Tukey's test for pair-wise comparisons ( $P$ values in the figures represent the pair-wise $P$ values). In case of unequal variances, data were rank transformed prior to the ANOVA. All analyses were carried out in SPSS 11.5.1 (SPSS, Inc., Chicago, IL, USA). $P$ values less than $0 \cdot 05$ were considered statistically significant.

\section{Results}

Fasting-induced hypothalamic prepro TRH $m R N A$ expression with and without leptin administration

We measured preproTRH mRNA expression by RT-PCR in the PVN in order to check our experimental setup. PreproTRH mRNA expression decreased after $24 \mathrm{~h}$ fasting and this decrease was prevented by leptin given twice during the fasting period (Fig. 1A). ANOVA analysis showed that leptin administration after $24 \mathrm{~h}$ to fasted animals resulted in significant preproTRH mRNA expression compared with fed animals which was caused by the fasting-induced decrease at $24 \mathrm{~h}$. No differences in starved and fed mice were observed at 4 and $8 \mathrm{~h}$ after leptin administration (Fig. 1B). We, therefore, conclude that we have administered adequate amounts of leptin to study differential effects of leptin and refeeding on pituitary thyroid hormone metabolism selectively.

Effect of leptin administration during fasting on thyroid hormone metabolism (Experiment 1)

Fasting resulted in significantly decreased serum leptin and thyroid hormone levels. Leptin administration, given twice during the fasting period, rapidly increased serum leptin levels although the half-life of mouse recombinant leptin is too short $\left(t_{1 / 2}=3 \mathrm{~h}\right.$ (Ahima et al. 1996)) to maintain high serum leptin levels during $24 \mathrm{~h}$ fasting similar to control mice. Serum $T_{3}$ and $T_{4}$ levels were slightly higher in the leptintreated group compared with starved mice, but still significantly lower compared with fed control mice (Table 1). Fasting also resulted in decreased pituitary TSH $\beta$, $\mathrm{D} 2$, and TR $\beta 2 \mathrm{mRNA}$ expression compared with fed control mice (Fig. 2). The decrease in TSH $\beta$ mRNA expression was not prevented by leptin administration, in contrast to the fasting-induced decrease of pituitary D2 mRNA expression. The fasting-induced decrease in TR $\beta 2$ tends to be prevented by leptin administration $(P=0 \cdot 09$; Fig. 3$)$.

\section{Effect of leptin administration after fasting on thyroid hormone metabolism (Experiment 2)}

Leptin administration after $24 \mathrm{~h}$ fasting resulted in significantly higher leptin levels at $28 \mathrm{~h}$ and lower levels at $32 \mathrm{~h}$, which is in agreement with the half-life of the hormone $\left(t_{1 / 2}=3 \mathrm{~h}\right)$. ANOVA analysis showed a significant difference
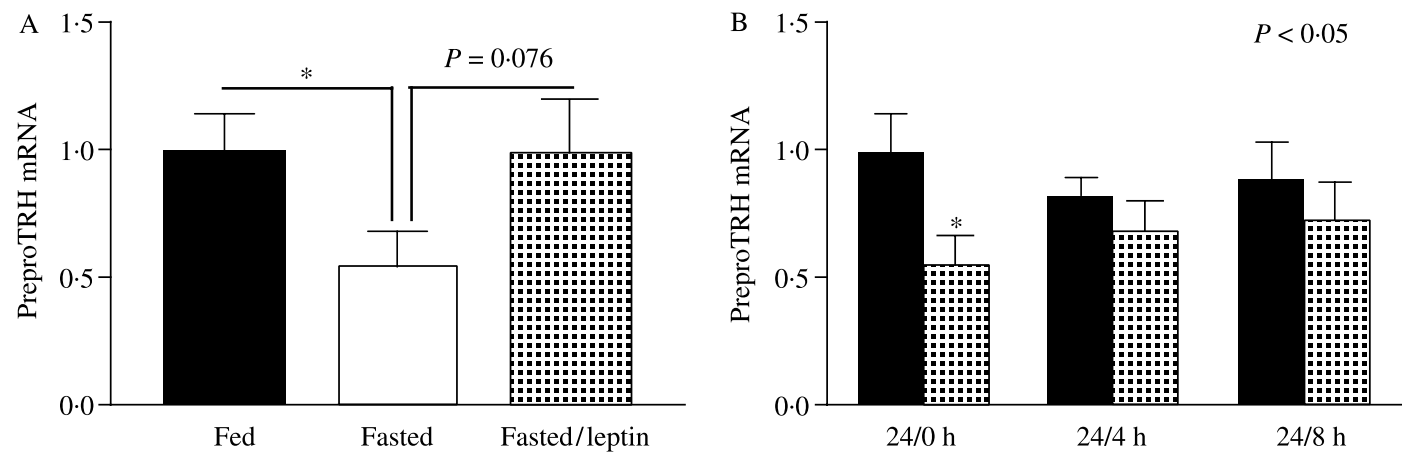

Figure 1 (A) Experiment 1: relative expression (normalized with the mean value of the $24 \mathrm{~h}$ control group, which was set at 1) of preproTRH mRNA in the paraventricular nucleus (PVN) of mice after $24 \mathrm{~h}$ fasting, while leptin was administered twice (at 0 and $8 \mathrm{~h}, 20 \mu \mathrm{g} / 0.5 \mathrm{ml}$, hatched bars) compared with fasted mice (open bars) and mice which received food ad libitum (black bars). (B) Experiment 2: relative expression (normalized to the mean value of the $24 \mathrm{~h}$ control group, which was set at 1) of preproTRH mRNA in the PVN of mice after $24 \mathrm{~h}$ fasting followed by leptin given once at $24 \mathrm{~h}$ euthanized $(20 \mu \mathrm{g} / 0 \cdot 5 \mathrm{ml}$, hatched bars euthanized after 4 and $8 \mathrm{~h}$ ) compared with mice which received food ad libitum (black bars). Mean values $(n=6) \pm$ S.E.M. of expression relative to hypoxanthine phosphoribosyl transferase (HPRT) are depicted; $P$ value indicates treatment difference between groups by ANOVA. Differences between groups at a single time point are indicated by $* P<0 \cdot 05$. 
Table 1 Serum thyroid hormone and leptin levels in mice after $24 \mathrm{~h}$ starvation. Leptin was administered twice (at 0 and $8 \mathrm{~h}, 20 \mu \mathrm{g} / 0 \cdot 5 \mathrm{ml}$, Experiment 1), after $24 \mathrm{~h}$ starvation followed by leptin given once at $24 \mathrm{~h}(20 \mu \mathrm{g} / 0 \cdot 5 \mathrm{ml}, \mathrm{t}$ at 28 and $32 \mathrm{~h}$, Experiment 2$)$ and after $24 \mathrm{~h}$ starvation followed by a period of refeeding of 4 or $24 \mathrm{~h}$ ( $\neq$ at 28 and $48 \mathrm{~h}$, Experiment 3). Each group was compared to its own control group as given in the table. Values were given as mean \pm s.E.M.

\begin{tabular}{|c|c|c|c|}
\hline Time $(\mathrm{h})$ & $\mathbf{T}_{\mathbf{3}}(\mathrm{nmol} / \mathrm{l})$ & $\mathbf{T}_{\mathbf{4}}(\mathrm{nmol} / \mathrm{l})$ & Leptin $(p g / m l)$ \\
\hline 24 & $1 \cdot 15 \pm 0 \cdot 04$ & $56 \pm 4$ & $3303 \pm 466$ \\
\hline 24 & $0 \cdot 56 \pm 0 \cdot 06^{*}$ & $25 \pm 2^{*}$ & $285 \pm 24^{*}$ \\
\hline 24 & $0.74 \pm 0.03^{*^{+}}$ & $32 \pm 3 *^{+}$ & $447 \pm 127^{*}$ \\
\hline $24 / 4$ & $1 \cdot 13 \pm 0 \cdot 11$ & $61 \pm 7$ & $2904 \pm 436$ \\
\hline $24 / 4$ & $0 \cdot 51 \pm 0 \cdot 10^{*}$ & $24 \pm 3^{*}$ & $4902 \pm 1293$ \\
\hline $24 / 8$ & $0.93 \pm 0.03$ & $47 \pm 6$ & $2418 \pm 541$ \\
\hline $24 / 8$ & $0 \cdot 58 \pm 0 \cdot 10^{*}$ & $20 \pm 2 *$ & $743 \pm 263^{*}$ \\
\hline 24 & $1 \cdot 18 \pm 0 \cdot 10$ & $69 \pm 7$ & $2330 \pm 327$ \\
\hline 24 & $0.75 \pm 0.11 *$ & $42 \pm 5^{*}$ & $182 \pm 32 *$ \\
\hline 28 & $1 \cdot 17 \pm 0 \cdot 04$ & $72 \pm 6$ & $1889 \pm 271$ \\
\hline $24 / 4$ & $0.84 \pm 0.03 *$ & $41 \pm 3^{*}$ & $2402 \pm 433$ \\
\hline 48 & $1 \cdot 20 \pm 0.06$ & $74 \pm 6$ & $1989 \pm 297$ \\
\hline $24 / 24$ & $0 \cdot 88 \pm 0 \cdot 11^{\ddagger}$ & $56 \pm 4^{\neq}$ & $3630 \pm 242 *$ \\
\hline
\end{tabular}

\section{Treatment}

Experiment 1: leptin given during fasting Control (food ad libitum) Fasting 24

Fasting/leptin

Experiment 2: leptin given after fasting Control (food ad libitum)/leptin 24/4 Fasting/leptin 24/4 Control (food ad libitum)/leptin $\quad 24 / 8$ Fasting/leptin

Experiment 3: refeeding after fasting Control (food ad libitum) 24 Fasting Control (food ad libitum) Fasting/refeeding Control (food ad libitum) Fasting/refeeding

${ }^{*} P<0 \cdot 01$ and ${ }^{\ddagger} P<0 \cdot 05$ compared with control treatment. ${ }^{\dagger} P<0 \cdot 05$ compared with fasted mice.

in serum $\mathrm{T}_{3}(P<0 \cdot 001)$ and $\mathrm{T}_{4}$ levels $(P<0 \cdot 001)$ between fasted mice, which received a single dose of leptin compared with fed mice which received leptin. The fasting-induced decrease in serum $T_{3}$ and $T_{4}$ was not restored after leptin administration and the levels were similar to the concentrations observed after $24 \mathrm{~h}$ fasting (Table 1). The fastinginduced decrease of TSH $\beta$ mRNA expression was also not restored 4 and $8 \mathrm{~h}$ after leptin injection compared with fed mice which received leptin (ANOVA, $P<0 \cdot 001$; Fig. 4A). ANOVA analysis revealed a significant difference in pituitary D2 $(P<0 \cdot 05)$ and TR $\beta 2(P<0 \cdot 01)$ mRNA expression between leptin given after $24 \mathrm{~h}$ fasting and to fed mice. This difference was restricted to $4 \mathrm{~h}$ after injection. Eight hours after leptin administration, pituitary D2 and TR $\beta 2$ mRNA expression was not different compared with control mice
(Fig. 4B and C). Altered TR $\beta 2$ and TSH $\beta$ mRNA expression in the fed control groups throughout the day reflects the circadian rhythm of these genes $\left(\mathrm{TR} \beta 2, P_{\text {time }}<0.01\right.$ and TSH $\left.\beta, P_{\text {time }}<0 \cdot 05\right)$.

Effect of refeeding on fasting-induced changes in thyroid hormone metabolism (Experiment 3)

Refeeding resulted in markedly increased serum leptin levels after 4 and $24 \mathrm{~h}$, which were not different (ANOVA, not significant) compared with fed control mice (although post hoc analysis indicates a significant difference at $24 \mathrm{~h}$ ). Refeeding, however, did not result in a complete recovery of serum $\mathrm{T}_{3}$ (ANOVA, $P<0 \cdot 001$ ) and $\mathrm{T}_{4}$ (ANOVA, $P<0 \cdot 001$ ) levels after $4 \mathrm{~h}$ and even after $24 \mathrm{~h}$ of refeeding compared with control mice
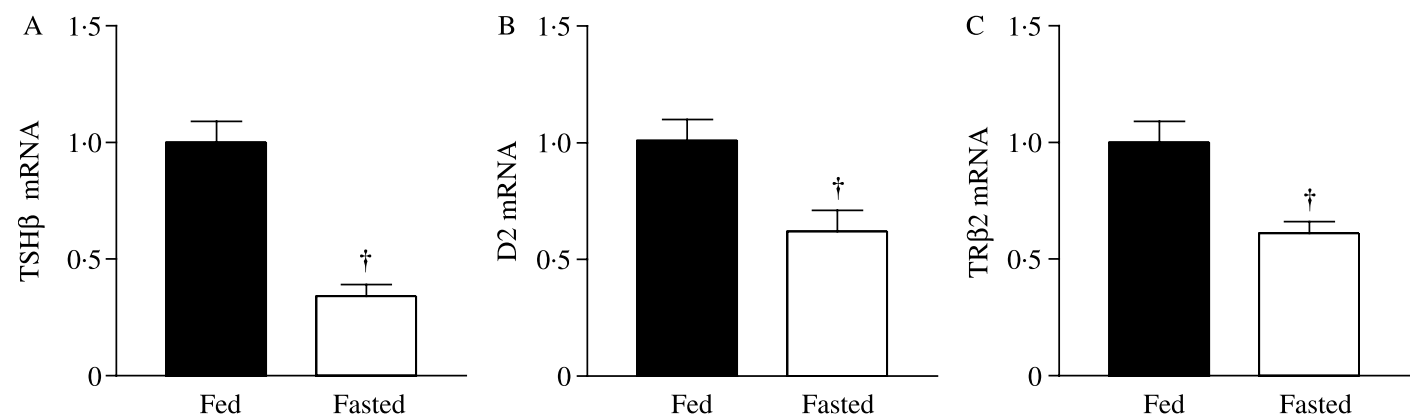

Figure 2 Relative expression (normalized with the mean value of the $24 \mathrm{~h}$ control group which was set at 1 ) of $(\mathrm{A})$ thyroid-stimulating hormone $\beta$ (TSH $\beta$ ), (B) type 2 deiodinase (D2), and (C) thyroid hormone receptor $\beta 2$ (TR $\beta 2$ ) mRNA in the pituitary of mice after $24 \mathrm{~h}$ fasting (open bars) compared with control mice which received food ad libitum (black bars). Mean values $(n=12) \pm$ s.E.M. of expression relative to HPRT are depicted; differences between groups at a single time point are indicated by ${ }^{\dagger} P<0 \cdot 01$. 

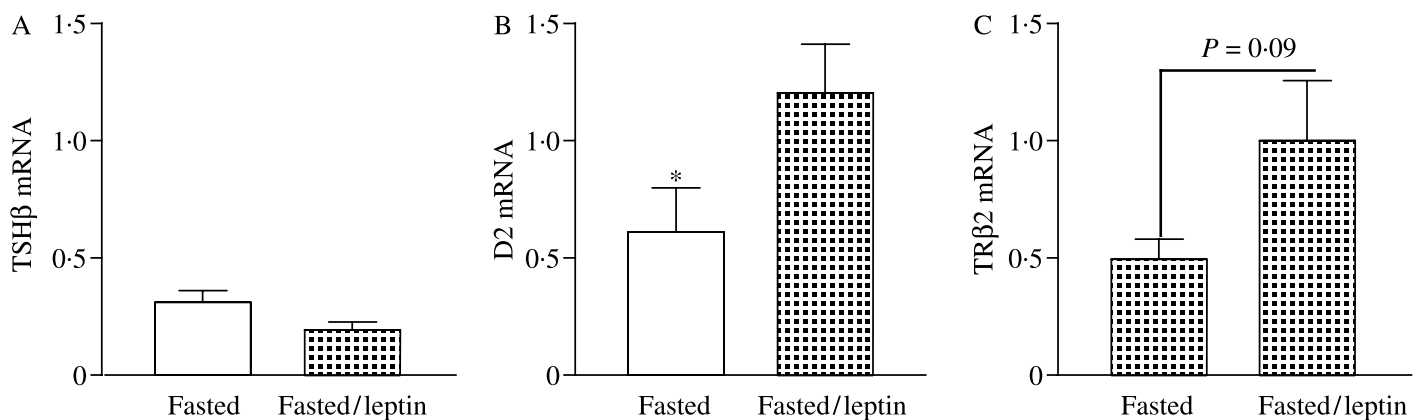

Figure 3 Relative expression (normalized with the mean value of the $24 \mathrm{~h}$ control group which was set at 1 ) of (A) TSH (B) D2, and (C) TR $32 \mathrm{mRNA}$ in the pituitary of mice after $24 \mathrm{~h}$ fasting, while leptin was administered twice (at 0 and $8 \mathrm{~h}, 20 \mu \mathrm{g} / 0 \cdot 5 \mathrm{ml}$, hatched bars) compared with fasted mice (open bars). Mean values $(n=6) \pm$ s.E.M. of expression relative to HPRT are depicted; differences between groups at a single time point are indicated by $* P<0 \cdot 05$.

(Table 1). Refeeding resulted in similar pituitary D2 and TR $\beta 2$ mRNA expression compared with fed control mice at 4 and $24 \mathrm{~h}$, while pituitary TSH $\beta$ mRNA expression was statistically different after refeeding compared with fed control mice $(P<$ $0 \cdot 01)$. Post hoc analysis indicated a significant difference at 0 and $4 \mathrm{~h}$ refeeding, but not after $24 \mathrm{~h}$ refeeding (Fig. 5).

\section{Discussion}

The aim of the present study was to evaluate (1) fastinginduced changes in pituitary TSH $\beta, \mathrm{D} 2$, and $\operatorname{TR} \beta$ mRNA expression of mice and (2) differential effects of leptin administration and refeeding on these changes. It is known that leptin administered during fasting reverses the fastinginduced decrease in TRH expression in the PVN (Legradi et al. 1997). We therefore punched the PVN area of the hypothalamus and measured preproTRH mRNA expression in order to validate our model, i.e. whether we used adequate amounts of leptin to influence the hypothalamic part of the HPT axis. A decrease in preproTRH mRNA expression was observed after $24 \mathrm{~h}$ fasting and this decrease was prevented by our leptin schedule. We, therefore, concluded that we administered adequate amounts of leptin to study the role of leptin on pituitary thyroid hormone metabolism.

Fasting induced decreased pituitary TSH $\beta$, D2, and TR $\beta$ mRNA expression as well as decreased serum thyroid hormone levels. We studied the influence of leptin administration given twice during the fasting period, a single dose of leptin given after the fasting period, and endogenous leptin induced by refeeding on the fasting induced alterations.

Leptin administration during fasting did not prevent the decrease in TSH $\beta$ mRNA expression despite restored hypothalamic preproTRH mRNA expression. In contrast, pituitary D2 and TR $\beta$ mRNA expression normalized when leptin was administered during the fasting period. The fastinginduced decrease in pituitary TSH $\beta$ mRNA expression was also not restored within $8 \mathrm{~h}$ after leptin administration. Our results seem in contrast with a previous study reporting that leptin intracerebrovascularly administered after a period of $48 \mathrm{~h}$ fasting restored the fasting-induced decrease in serum TSH in rats (Seoane et al. 2000), which might be due to the different route of administration (i.c.v. vs i.p.). Our results also, did not agree completely with the study of Ortiga-Carvalho
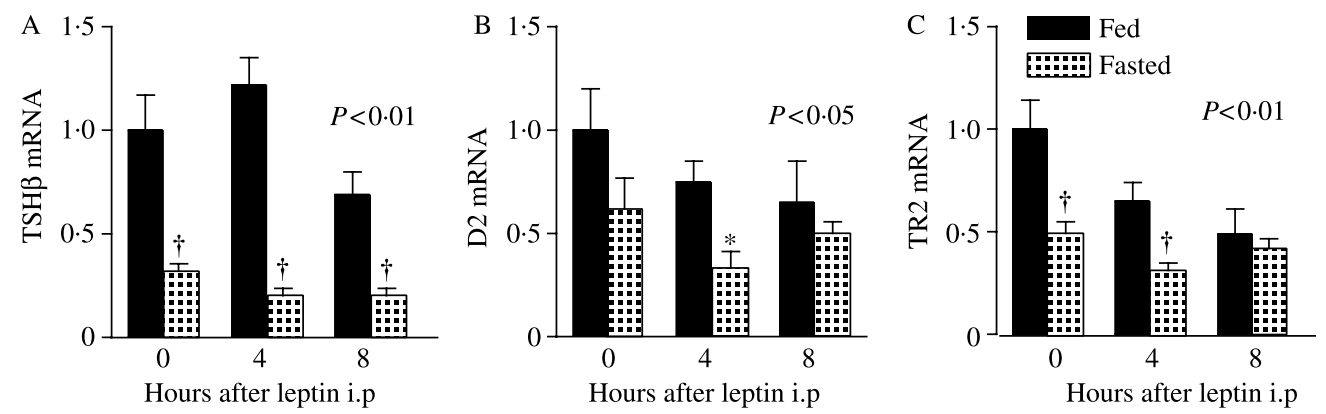

Figure 4 Experiment 2: relative expression (normalized to the mean value of the $24 \mathrm{~h}$ control group which was set at 1) of (A) TSH $\beta$, (B) D2, and (C) TR 32 mRNA in the pituitary of mice after $24 \mathrm{~h}$ fasting followed by leptin given once at $24 \mathrm{~h}(20 \mu \mathrm{g} / 0 \cdot 5 \mathrm{ml}$, euthanized after 4 and $8 \mathrm{~h})$ compared with mice which received food ad libitum and leptin $(20 \mu \mathrm{g} / 0.5 \mathrm{ml}$, + after 4 and $8 \mathrm{~h})$. Mean values $(n=6) \pm$ s.E.M. of expression relative to HPRT are depicted; $P$ value indicates treatment difference between groups by ANOVA. Differences between groups at a single time point is indicated by $* P<0 \cdot 05$ and ${ }^{\dagger} P<0 \cdot 01$. 

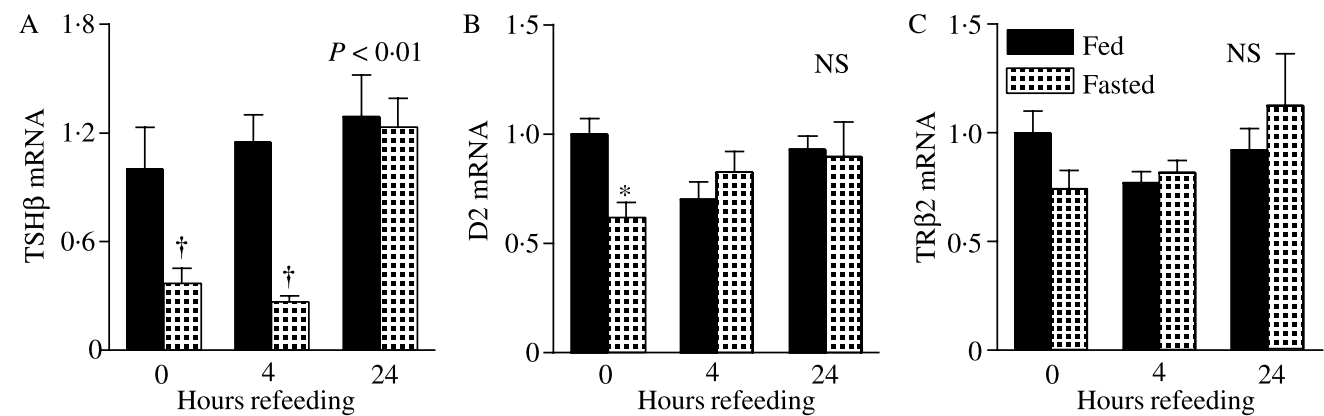

Figure 5 Experiment 3: relative expression (normalized to the mean value of the $24 \mathrm{~h}$ control group which was set at 1) of (A) TSH $\beta,(B) D 2$, and (C) TR $\beta 2$ mRNA in the pituitary of mice after $24 \mathrm{~h}$ fasting followed by a period of refeeding ( $4 \mathrm{~h}$, euthanized at 28 and $24 \mathrm{~h}$ ) compared with mice which received food ad libitum. Mean values $(n=6)$ \pm S.E.M. of expression relative to HPRT are depicted; $P$ value indicates treatment difference between groups by ANOVA. Differences between groups at a single time point are indicated by ${ }^{*} P<0 \cdot 05$ and ${ }^{\dagger} P<0 \cdot 01, N S$ : not significant.

et al. (2002), who showed that leptin administration to fed rats resulted in an increase in serum TSH after $2 \mathrm{~h}$, although the leptin-treated group was not compared with a control group at the same time point, so an effect of the diurnal rhythm cannot be excluded. Furthermore, they administered 0.08 and $0.16 \mu \mathrm{g}$ leptin/g body weight (BW) (in our study, mice received $1 \mu \mathrm{g} / \mathrm{g} \mathrm{BW}$ ) and only administration of $0.08 \mu \mathrm{g}$ leptin/g BW increased serum TSH levels, while administration of $0.16 \mu \mathrm{g}$ leptin $/ \mathrm{g} \mathrm{BW}$ did not have an effect, which is in agreement with our results (Ortiga-Carvalho et al. 2002). However, notwithstanding the fact that we cannot exclude the possibility that pituitary TSH $\beta$ mRNA expression was not restored $8 \mathrm{~h}$ after leptin injection, because of lower serum leptin levels compared with those in fed mice, different mechanisms might be involved in the fasting-induced decrease in pituitary TSH $\beta$ vs $\mathrm{D} 2$ and TR $\beta 2$ mRNA expression. Restored pituitary D2 and TR $\beta 2$ mRNA expression might be leptin and/or TRH dependent, while the fasting-induced decrease in pituitary TSH $\beta$ appears to be not. The cellular expression of these genes are not likely to explain the observed differences because Li \& Boyages (1997) demonstrated specific (nuclear) localization of TR $\beta 2$ protein in TSH-producing cells of the anterior pituitary in the rat, whereas Alkemade et al. (2005) showed that in human pituitary D2 does not co-localize with TSH, but is expressed in pituitary folliculate-stellate (FS) cells. It has been postulated that leptin has a predominant role in the fasting-induced changes in pituitary TSH $\beta$ expression via decreased TRH expression in the PVN (Seoane et al. 2000), but our results do not support this hypothesis. Many other hypothalamic neuropeptides (i.e. POMC, neuropeptide Y (NPY), AGRP, growth hormone-releasing hormone, and opioids) and humoral factors are affected by fasting (Shi et al. 1993, Swart et al. 2002), and, perhaps, these factors are involved in pituitary TSH $\beta$ mRNA expression during fasting independently of leptin. Furthermore, specific proteins (e.g. Pit-1 and retinoid $\mathrm{X}$ receptor- $\gamma$ ) expressed amongst others in the thyrotropic cells play an important role in TSH $\beta$ gene expression (Shupnik 2000), and it is possible that a period of fasting affects these proteins also independently of leptin. A recent study has shown that neuromedin B (NB), a bombesinrelated peptide, highly concentrated in the pituitary and expressed in the thyrotropic cell (Steel et al. 1988) is involved in TSH gene regulation (Oliveira et al. 2006). It has been postulated that NB is an inhibitor of TSH secretion, while it is also known that NB increased during fasting and therefore is probably responsible for the decrease in TSH secretion (Ortiga-Carvalho et al. 1997). The in vivo effects of leptin on $\mathrm{NB}$ are not very consistent, only very low doses given to fed rats decreased $\mathrm{NB}$ within $2 \mathrm{~h}$, while higher doses of leptin did not have an effect (Ortiga-Carvalho et al. 2003) possibly explaining why the fasting-induced decrease in pituitary TSH $\beta$ mRNA cannot be restored by leptin administration in our experimental setting.

Leptin exerts its action via the leptin receptor (OB-R), which belongs to the family of class I cytokine receptors and is present in many tissues, including normal mouse pituitary and a mouse FS cell line (Jin et al. 2000). Activation of this receptor results in the activation of the cytokine-related JAK/ STAT signaling pathway. Leptin is also capable of activating nuclear factor (NF)- $\mathrm{KB}$ in dendritic cells (Mattioli et al. 2005) suggesting that leptin might activate NF- $\kappa \mathrm{B}$ in pituitary FS cells, as it is known that these cells use the NF- $\mathrm{KB}$ signaling pathway (Lohrer et al. 2000).

Fekete et al. (2004) have shown that the D2 gene can be activated by the NF- $\kappa \mathrm{B}$ second messenger system in an in vitro cell system and, therefore, the activation of NF- $\mathrm{BB}$ in FS cells via leptin might be an explanation for the normalization of pituitary D2 mRNA expression. The experimental design (time-course, moment, and amount of leptin given), however, seems critical because a single injection of leptin after $24 \mathrm{~h}$ fasting is not enough to restore pituitary D2 expression within $4 \mathrm{~h}$, while leptin given during the fasting period completely prevents the fasting-induced decrease in pituitary D2 mRNA expression. The alterations in pituitary TR $\beta 2$ mRNA expression correlate positively with those in pituitary D2 mRNA expression. D2 gene expression, however, is negatively regulated at the transcriptional level by $\mathrm{T}_{3}$, probably via the TR $\beta$ (Gereben \& Salvatore 2005), 
suggesting that decreased TR $\beta 2$ mRNA does not explain decreased pituitary D2 mRNA expression.

Fasting induces decreased TR $\beta 2$ mRNA expression and leptin prevents this decrease only when administered during fasting. It is known that serum-free fatty acid (FFA) concentrations increase during fasting (Suzuki et al. 2002). Effects of FFA on thyroid hormone receptor function have been known for many years, especially inhibition of thyroid hormone binding to the TR (Wiersinga et al. 1988). It has also been shown that sodium butyrate, a short-chain fatty acid, inhibits TR $\beta 2$ mRNA expression selectively by rapidly repressing TR $\beta 2$ gene transcription (Lazar 1990). Leptin administration decreases serum FFA concentrations (Kalaivanisailaja et al. 2003), which thus could partly explain restored pituitary TR $\beta 2$ mRNA expression as observed in the present study. Peroxisome proliferator activated receptor- $\gamma$, another nuclear receptor of the thyroid hormone family, decreases significantly in the pituitary after $24 \mathrm{~h}$ fasting, probably via FFA (Nakamura et al. 2004) without changes in the basal hypothalamus, which supports this notion (Wiesner et al. 2004).

The observed alterations in pituitary thyroid hormone metabolism were compared with those in starved animals who were refed in order to differentiate between effects of leptin per se and refeeding. Although serum leptin reached similar levels after $4 \mathrm{~h}$ refeeding and leptin treatment, altered pituitary D2 and TR $\beta 2$ mRNA expression was completely abolished within $4 \mathrm{~h}$ by refeeding, but not by leptin administration. This suggests that other post ingestion signals in addition to leptin are necessary to influence pituitary D2 and TR $\beta 2$ mRNA expression rapidly. Eight hours after leptin treatment, however, pituitary $\mathrm{D} 2$ and TR $\beta 2$ mRNA expression were not different compared with control mice indicating that leptin alone influences pituitary D2 and TR $\beta 2$ mRNA expression more slowly. This might be explained by the different response of corticosterone on leptin administration or refeeding. Ahima et al. (1996) showed that the fasting-induced increase in serum corticosterone was partly prevented by leptin administration, while it has been shown that refeeding for a period of $60 \mathrm{~min}$ resulted in complete recovery of serum corticosterone levels induced by fooddeprivation in rats (Millward et al. 1983). Nevertheless, our results are in agreement with a study of Swart et al. (2002) reporting that refeeding partly restores fasting-induced alterations in hypothalamic NPY and POMC mRNA expression within $6 \mathrm{~h}$, while leptin administration after food deprivation is not sufficient to affect mRNA levels.

In conclusion, fasting decreases pituitary TSH $\beta, D 2$, and TR $\beta 2$ mRNA expression and leptin treatment during the fasting period prevents the decrease in D2 and TR $\beta 2 \mathrm{mRNA}$, but not in TSH $\beta$ mRNA expression. Leptin administration after fasting influences D2 and TR $\beta 2$ mRNA expression only after $8 \mathrm{~h}$, while refeeding (which also results in high serum leptin levels) restores D2 and TR $\beta 2$ mRNA expression completely within $4 \mathrm{~h}$. Leptin may, theoretically, influence these genes by several mechanisms (decreasing FFA concentrations, activating the NFKB pathway), but our results indicate that other post ingestion signals in addition to leptin may be necessary to rapidly modulate the fasting-induced decrease in pituitary D2 and TR $\beta 2$ mRNA expression.

\section{Acknowledgements}

We would like to thank J Daalhuisen (Department of Experimental Internal Medicine), M Platvoet-ter Schiphorst and A Alkemade (Department of Endocrinology and Metabolism) for expert biotechnical assistance and the Staff of the Laboratory of Endocrinology for measuring thyroid hormones. Dr M Tanck (Department of Clinical Epidemiology) is thanked for his advice on the statistical analyses. We are grateful to Dr C van Eden (National Institute of Brain Research, Amsterdam) for his assistance with punching the PVN. The authors declare that there is no conflict of interest that would prejudice the impartiality of this scientific work.

\section{References}

Ahima RS, Prabakaran D, Mantzoros C, Qu D, Lowell B, Maratos-Flier E \& Flier JS 1996 Role of leptin in the neuroendocrine response to fasting. Nature 382 250-252.

Alkemade A, Friesema EC, Unmehopa UA, Fabriek BO, Kuiper GG, Leonard JL, Wiersinga WM, Swaab DF, Visser TJ \& Fliers E 2005 Neuroanatomical pathways for thyroid hormone feedback in the human hypothalamus. Journal of Clinical Endocrinology and Metabolism 90 4322-4334.

Blake NG, Eckland DJ, Foster OJ \& Lightman SL 1991 Inhibition of hypothalamic thyrotropin-releasing hormone messenger ribonucleic acid during food deprivation. Endocrinology 129 2714-2718.

Boelen A, Kwakkel J, Thijssen-Timmer DC, Alkemade A, Fliers E \& Wiersinga WM 2004 Simultaneous changes in central and peripheral components of the hypothalamus-pituitary-thyroid axis in lipopolysaccharide-induced acute illness in mice. Journal of Endocrinology 182 315-323.

Chowdhury I, Chien JT, Chatterjee A \& Yu JY 2004 Effects of leptin and neuropeptide-Y on transcript levels of thyrotropin beta and common alpha subunits of rat pituitary cells in vitro. Life Sciences 75 2897-2909.

Coppola A, Meli R \& Diano S 2005 Inverse shift in circulating corticosterone and leptin levels elevates hypothalamic deiodinase type 2 in fasted rats. Endocrinology 146 2827-2833.

Diano S, Naftolin F, Goglia F \& Horvath TL 1998 Fasting-induced increase in type II iodothyronine deiodinase activity and messenger ribonucleic acid levels is not reversed by thyroxine in the rat hypothalamus. Endocrinology 139 2879-2884.

Fekete C, Gereben B, Doleschall M, Harney JW, Dora JM, Bianco AC, Sarkar S, Liposits Z, Rand W, Emerson C, Kacskovics I, Larsen PR \& Lechan RM 2004 Lipopolysaccharide induces type 2 iodothyronine deiodinase in the mediobasal hypothalamus: implications for the nonthyroidal illness syndrome. Endocrinology 145 1649-1655.

Flier JS, Harris M \& Hollenberg AN 2000 Leptin, nutrition, and the thyroid: the why, the wherefore, and the wiring. Journal of Clinical Investigations 105 859-861.

Franklin KBJaPG 1997 The Mouse Brain in Stereotaxic Coordinates. San Diego, CA: Academic Press.

Gereben B \& Salvatore D 2005 Pretranslational regulation of type 2 deiodinase. Thyroid 15 855-864.

Guo F, Bakal K, Minokoshi Y \& Hollenberg AN 2004 Leptin signaling targets the thyrotropin-releasing hormone gene promoter in vivo. Endocrinology 145 2221-2227. 
Jin L, Zhang S, Burguera BG, Couce ME, Osamura RY, Kulig E \& Lloyd RV 2000 Leptin and leptin receptor expression in rat and mouse pituitary cells. Endocrinology $141333-339$.

Kalaivanisailaja J, Manju V \& Nalini N 2003 Lipid profile in mice fed a highfat diet after exogenous leptin administration. Polish Journal of Pharmacology $55763-769$

Lazar MA 1990 Sodium butyrate selectively alters thyroid hormone receptor gene expression in GH3 cells. Journal of Biological Chemistry 265 17474-17477.

Legradi G, Emerson CH, Ahima RS, Flier JS \& Lechan RM 1997 Leptin prevents fasting-induced suppression of prothyrotropin-releasing hormone messenger ribonucleic acid in neurons of the hypothalamic paraventricular nucleus. Endocrinology 138 2569-2576.

Li M \& Boyages SC 1997 Expression of beta2-thyroid hormone receptor in euthyroid and hypothyroid rat pituitary gland: an in situ hybridization and immunocytochemical study. Brain Research 773 125-131.

Lohrer P, Gloddek J, Nagashima AC, Korali Z, Hopfner U, Pereda MP, Arzt E, Stalla GK \& Renner U 2000 Lipopolysaccharide directly stimulates the intrapituitary interleukin-6 production by folliculostellate cells via specific receptors and the p38alpha mitogen-activated protein kinase/nuclear factor-kappaB pathway. Endocrinology 141 4457-4465.

Mattioli B, Straface E, Quaranta MG, Giordani L \& Viora M 2005 Leptin promotes differentiation and survival of human dendritic cells and licenses them for Th1 priming. Journal of Immunology 174 6820-6828.

Millward DJ, Odedra B \& Bates PC 1983 The role of insulin, corticosterone and other factors in the acute recovery of muscle protein synthesis on refeeding food-deprived rats. Biochemical Journal 216 583-587.

Nakamura MT, Cheon Y, Li Y \& Nara TY 2004 Mechanisms of regulation of gene expression by fatty acids. Lipids 39 1077-1083.

Oliveira KJ, Ortiga-Carvalho TM, Cabanelas A, Veiga MA, Aoki K, OhkiHamazaki H, Wada K, Wada E \& Pazos-Moura CC 2006 Disruption of neuromedin $\mathrm{B}$ receptor gene results in dysregulation of the pituitarythyroid axis. Journal of Molecular Endocrinology 36 73-80.

Ortiga-Carvalho TM, Curty FH, Nascimento-Saba CC, Moura EG, Polak J \& Pazos-Moura CC 1997 Pituitary neuromedin B content in experimental fasting and diabetes mellitus and correlation with thyrotropin secretion. Metabolism 46 149-153.

Ortiga-Carvalho TM, Oliveira KJ, Soares BA \& Pazos-Moura CC 2002 The role of leptin in the regulation of TSH secretion in the fed state: in vivo and in vitro studies. Journal of Endocrinology 174 121-125.

Ortiga-Carvalho TM, Oliveira KJ, Morales MM, Martins VP \& Pazos-Moura CC 2003 Thyrotropin secretagogues reduce rat pituitary neuromedin B, a local thyrotropin release inhibitor. Experimental Biology and Medicine 228 1083-1088.

Ramakers C, Ruijter JM, Deprez RH \& Moorman AF 2003 Assumption-free analysis of quantitative real-time polymerase chain reaction (PCR) data. Neuroscience Letters 339 62-66.
Seoane LM, Carro E, Tovar S, Casanueva FF \& Dieguez C 2000 Regulation of in vivo TSH secretion by leptin. Regulatory Peptides 92 25-29.

Shi ZX, Levy A \& Lightman SL 1993 The effect of dietary protein on thyrotropin-releasing hormone and thyrotropin gene expression. Brain Research 606 1-4.

Shupnik MA 2000 Thyroid hormone suppression of pituitary hormone gene expression. Reviews of Endocrinology and Metabolic Disorders 1 35-42.

Steel JH, Van Noorden S, Ballesta J, Gibson SJ, Ghatei MA, Burrin J, Leonhardt U, Domin J, Bloom SR \& Polak JM 1988 Localization of 7B2, neuromedin $\mathrm{B}$, and neuromedin $\mathrm{U}$ in specific cell types of rat, mouse, and human pituitary, in rat hypothalamus, and in 30 human pituitary and extrapituitary tumors. Endocrinology 122 270-282.

Suzuki J, Shen WJ, Nelson BD, Selwood SP, Murphy GM, Jr, Kanehara H, Takahashi S, Oida K, Miyamori I \& Kraemer FB 2002 Cardiac gene expression profile and lipid accumulation in response to starvation. American Journal of Physiology 283 E94-E102.

Swart I, Jahng JW, Overton JM \& Houpt TA 2002 Hypothalamic NPY, AGRP, and POMC mRNA responses to leptin and refeeding in mice. American Journal of Physiology 283 R1020-R1026.

Sweet MJ, Leung BP, Kang D, Sogaard M, Schulz K, Trajkovic V, Campbell CC, Xu D \& Liew FY 2001 A novel pathway regulating lipopolysaccharide-induced shock by ST2/T1 via inhibition of Toll-like receptor 4 expression. Journal of Immunology 166 6633-6639.

van Haasteren GA, Linkels E, Klootwijk W, Van Toor H, Rondeel JM, Themmen AP, de Jong FH, Valentijn K, Vaudry H \& Bauer K 1995 Starvation-induced changes in the hypothalamic content of prothyrotrophin-releasing hormone (proTRH) mRNA and the hypothalamic release of proTRH-derived peptides: role of the adrenal gland. Journal of Endocrinology 145 143-153.

Wiersinga WM 2005 Nonthyroidal illness. In The Thyroid, pp 246-263. Eds LE Braverman \& RD Utiger. Philadelphia: Lipincott.

Wiersinga WM \& Chopra IJ 1982 Radioimmunoassay of thyroxine $\left(\mathrm{T}_{4}\right)$, 3,5,3'-triiodothyronine $\left(T_{3}\right), 3,3^{\prime}, 5^{\prime}$-triiodothyronine (reverse $T_{3}, \mathrm{rT}_{3}$ ), and 3,3'-diiodothyronine $\left(\mathrm{T}_{2}\right)$. Methods of Enzymology 84 272-303.

Wiersinga WM, Chopra IJ \& Teco GN 1988 Inhibition of nuclear $\mathrm{T}_{3}$ binding by fatty acids. Metabolism 37 996-1002.

Wiesner G, Morash BA, Ur E \& Wilkinson M 2004 Food restriction regulates adipose-specific cytokines in pituitary gland but not in hypothalamus. Journal of Endocrinology 180 R1-R6.

\section{Received in final form 19 April 2006 \\ Accepted 21 April 2006 \\ Made available online as an Accepted Preprint 10 May 2006}

